\section{Perceptions of social capital and cost-related non-adherence to medication among the elderly}

\author{
Percepções de capital social e subutilização \\ de medicamentos por motivos financeiros \\ entre idosos
}

\author{
1 Centro de Pesquisas René \\ Rachou, Fundação Oswaldo \\ Cruz, Belo Horizonte, Brasil. \\ 2 Núcleo de Estudos \\ em Saúde Pública e \\ Envelhecimento, Fundação \\ Oswaldo Cruz/Universidade \\ Federal de Minas Gerais, \\ Belo Horizonte, Brasil. \\ Correspondence \\ T. C. B. Luz \\ Centro de Pesquisas René \\ Rachou, Fundação Oswaldo \\ Cruz. \\ Av. Augusto de Lima 1715, \\ Belo Horizonte, $M G$ \\ 30190-002, Brasil. \\ tatianachama@cpqrr.fiocruz.br
}

\begin{abstract}
The aim of this study was to examine the association between social capital and cost-related nonadherence $(C R N)$ in an elderly population, using data from 1,134 respondents to the Greater Metropolitan Belo Horizonte Health Survey. CRN was lower for those elderly with a better perception of attachment to their neighbourhoods ( $P R=$ 0.68; 95\%CI: 0.50-0.94), with more social contacts (one to five, $P R=0.49$; $95 \% C I$ : $0.30-0.80$ and more than five, $P R=0.42$; 95\%CI: 0.26-0.67), and with private health insurance coverage $(P R=0.64$; 95\%CI: 0.45-0.93). Meanwhile, CRN was significantly higher for those with fair to poor self-rated health ( $P R=1.66$; 95\%CI: $0.95-2.90$ and $P R=2.62$; 95\%CI: 1.46-4.71 respectively), with multiple comorbidities (two, $P R=3.45$; 95\% CI: 1.38-8.62 and three or more, $P R=4.42$; 95\%CI: 1.74-11.25), and with a lower frequency of physician-patient dialogue about health/treatment (rarely/never, $P R=$ 1.91; 95\%CI: 1.16-3.13). These findings highlight the need to take into account the social context in future research on CRN.
\end{abstract}

Medication Adherence; Social Conditions; Pharmacoepidemiology; Aged
Tatiana Chama Borges Luz 1 Antônio Ignácio de Loyola Filho 2 Maria Fernanda Lima-Costa 2

\section{Introduction}

Cost-related medication non-adherence (CRN) is estimated to occur in $13 \%$ to $32 \%$ of elderly persons 1,2. Patients who reduce medical costs by taking their medications sporadically, splitting pills, using smaller doses than prescribed, or delaying refills may do not achieve the full therapeutic benefits of therapy ${ }^{3}$. Indeed, this subset of non-adherence has been associated with serious health consequences, including decrements in self-reported health status 4 , increased hospital admissions 4,5 , and death 5 .

Although the costs of prescription drugs pose a growing burden on the elderly 6 , they cannot fully explain the occurrence of CRN, since many patients continue using their medication as prescribed despite the cost, and others forgo medication due to costs when they may be able to afford those treatments 2,7 .

Since individuals' responses to cost pressures cannot be predicted solely based on their level of financial burden, Piette et al. 8 suggest that the cost-adherence relationship is modified by multiple social contextual factors. However, this has never been formally tested 9 .

One of the key components of social context is social capital 10 , which can be described as a feature of social structure based on reciprocity, trust, and mutual obligations, which serve to facilitate action for shared benefit, through membership in civic and community networks and 
other social structures 11,12,13. Despite the controversies that surround this literature 14,15 , social capital theory has become prominent in public health research, since it has been linked, both in the general as well as in elderly populations, to a wide range of health measures, including perceived health status $16,17,18$, quality of life 19 , and access to health care 20 .

With respect to medical treatment, social capital may determine adherence through its influence on health-related behaviours, on transmission of health information, on access to health services, and through social control over deviant health-related behaviour 18 . The underlying, but yet unproven assumption, has been that low levels of social capital might increase the probability of CRN.

This study aims to investigate the association between perceived social capital and CRN among older people, after controlling for sociodemographic determinants, health conditions and health system characteristics.

\section{Methods}

The Greater Metropolitan Belo Horizonte Health Survey

The data were derived from the health survey conducted in the Greater Metropolitan region of Belo Horizonte city from May 1st to July 31st, 2003. The Metropolitan Region of Belo Horizonte is composed of around 20 municipalities, representing the third largest metropolitan area in Brazil in terms of both population (4.4 million inhabitants) and gross domestic product 21 .

The survey was a two-stage stratified cluster sample, using the Brazilian census tract as the primary selection unit and household as the sample unit. The sample was based on 7,500 households with 24,000 residents. All residents aged 18 years or older were eligible for the survey. A total of 13,701 respondents completed the questionnaire (1,778 aged 60 years or older), yielding a response rate of $79 \%$. Participants' distribution by gender and age was similar to that observed among the total Greater Metropolitan Belo Horizonte population aged 18 or older. More details on the survey can be seen in another publication 21 .

For the present study, we selected all of the 1,386 participants from this survey aged 60 years or older with a history of drug prescription in the previous 30 days.

The Greater Metropolitan Belo Horizonte Health Survey was approved by the Institutional Review Board of the Oswaldo Cruz Foundation in Belo Horizonte, Minas Gerais State, Brazil, in 2001.

\section{Outcome variable}

For the analysis, we constructed a summary indicator of CRN based on other studies that have used a similar approach 1,6,7: the value "yes" was assigned if a respondent indicated "yes/ever during the previous 30 days" on any of the following: "did not have a completed prescription because it was too expensive"; "skipped doses to make the drug last longer"; or "took smaller doses of a drug to make the medication last longer".

\section{Covariates}

\section{- Measurement of individual-level social capital}

We measured individual social capital through three different broad and multidimensional indexes: neighbourhood trust, perception of attachment to the neighbourhood, and perception of physical environment. We also used a question on perception of help. The construction of social capital indexes was similar to Baron-Epel et al. 17. Some of the original questions were recoded in reverse order to ensure data consistency. We computed Cronbach's alpha coefficient 22 to check the reliability of the variables used for constructing each of the social capital indexes. The estimated coefficients show a moderate to high reliability, varying from 0.315 (for responses to questions that enter into the construction of perception of physical environment), 0.317 (for social trust index) to 0.678 (for perception of attachment to the neighbourhood index) 16. The indexes and the question are described below:

\section{- Neighbourhood trust index}

Two questions (yes/no answer) were used to assess neighbourhood trust: "Thinking of your neighbourhood, would you say most people can be trusted?" 23,24 and "Do you think most people in your neighbourhood would take advantage of you if they got a chance?" 23,24. A composite variable was calculated to represent the neighbourhood trust index by adding the positive answers. The range of answers for this index was 0-2. Low neighbourhood trust was coded 0 and included the scores 0 and 1 . High neighbourhood trust was coded 1 and included score 2 .

\section{- Index of perception of attachment to the neighbourhood}

Three survey questions (yes/no answer) measured this index: "Do you feel comfortable in your neighbourhood, do you think of the area around 
you as a real home, not just a place?" 25; “Would you like to move out of this neighbourhood?" 25,26, and "Do you think your neighbourhood is a good place for you to live? Do you like your neighbours and your house?". A composite variable was calculated to represent the social trust index by adding the positive answers. The range of answers for this index was 0 -3. Low perception of attachment to the neighbourhood was coded 0 and included the scores 0 , 1, and 2. High perception of attachment to the neighbourhood was coded 1 and included score 3 .

\section{- Perception of physical environment index}

This index was based on two questions (yes/no answer): "Are you satisfied with how your neighbourhood is being taken care of?" 25 and "Do you think your neighbourhood is a good place for children to play; andagood place to raise teenagers?" 25. A composite variable was calculated to represent perception of the physical environment index by adding the positive answers. The range of answers for this index was $0-2$. Low perception of physical environment was coded 0 and included the scores 0 and 1 . High perception of physical environment was coded 1 and included score 2 .

\section{- Perception of help}

This was assessed using one question (with a yes / no answer): "Do you think that people in your neighbourhood are willing to help each other?" 17. High perceived helpfulness was coded 1, and low perceived helpfulness was coded 0 .

\section{Other covariates}

The following groups of variables included in the analysis were previously described as associated with CRN 1,7,27,28,29,30,31: (1) sociodemographic characteristics: gender, age, skin colour (self-reported), education (number of complete years of schooling); (2) health conditions: selfrated health and number of chronic conditions. For chronic conditions we used a checklist of 12 conditions based on the report of previous medical diagnosis (arthritis/rheumatism, cancer, hypertension, asthma/bronchitis, diabetes mellitus, angina pectoris, myocardial infarction, heart disease, stroke, lower back pain, renal disease, and depression); (3) health system characteristics: private health insurance and quality of the relationship between physician and patient (frequencies of physician-patient dialogue about health/treatment).

In this study, as an indicator of socioeconomic status, we used schooling, a characteristic that generally does not change after a certain age, instead of income, a characteristic which can change during the individual's lifetime 32 .

\section{Statistical analyses}

We first conducted univariate analysis, based on robust Poisson regression 33 and Pearson's chisquare test to explore the association between characteristics of the study population and social capital measures and CRN (a binomial variable: 0 = no non-adherence due to cost; $1=$ costrelated medication non-adherence, was used as the dependent variable). Then we conducted the multivariate analyses, based on robust Poisson regression analyses, to assess the independent association between CRN and each variable. All independent variables with a p-value of less than 0.20 in the univariate analysis were initially included in the multivariate models. A backward elimination process eliminated non-significant variables at $\mathrm{p}$-value $<0.05$. The prevalence ratio (PR), 95\% confidence interval (95\%CI), and $\mathrm{p}$-value are presented. The variance inflation factor (VIF) was also estimated to exclude the possibility of overlapping of highly-correlated independent variables (maximum VIF value 1.42 and minimum tolerance index 0.71 ), showing that multicollinearity was not a concern in fitting these models. All statistical analyses were carried out using the survey (svy) command in the Stata software, version 10.0 (Stata Corp., College Station, USA).

\section{Results}

From 1,386 participants of the health survey with a history of drug prescription in the previous 30 days, there were 1,017 (73.4\%) for whom complete data on all study variables were available, and these were included in this analysis. Participants and non-participants were similar in terms of mean age (70.3 years and 69.9 years, respectively, $\mathrm{p}=0.417)$, but females are overrepresented in our study (66\% and $55.9 \%$, respectively, $\mathrm{p}=0.002$ ).

As shown in Table $1,13.4 \%$ of respondents answered affirmatively to cost-related medication non-adherence questions, with the following predominant characteristics: women $(66 \%)$, non-white skin colour (52.8\%), and less than seven years of schooling $(76.7 \%)$. In relation to social capital variables, the majority of participants reported low levels of trust in people in their neighbourhood (82.6\%), and about one third had low perceptions of attachment to both their neighbourhoods and the physical environment. 
Characteristics of the study sample. Greater Metropolitan Region of Belo Horizonte, Minas Gerais State, Brazil, 2003.

\begin{tabular}{|c|c|}
\hline Characteristics & $\%$ or mean (SD) \\
\hline Female gender & 66.0 \\
\hline Age [mean (SD)] & $70.3(7.8)$ \\
\hline Non-white skin colour & 52.8 \\
\hline Schooling $<7$ complete years & 76.7 \\
\hline \multicolumn{2}{|l|}{ Self-rated health } \\
\hline Excellent/Good & 33.2 \\
\hline Fair & 44.6 \\
\hline Poor/Very poor & 16.2 \\
\hline \multicolumn{2}{|l|}{ Number of self-reported chronic diseases } \\
\hline None & 13.5 \\
\hline 1 & 30.3 \\
\hline 2 & 25.8 \\
\hline $3+$ & 30.5 \\
\hline No private health insurance coverage & 53.1 \\
\hline Physician-patient dialogue about health/treatment (always or most of the time) & 95.7 \\
\hline \multicolumn{2}{|l|}{ Social capital variables } \\
\hline Neighbourhood trust (low) & 82.6 \\
\hline Perception of attachment to the neighbourhood (low) & 32.5 \\
\hline Perception of physical environment (low) & 36.8 \\
\hline Perception of help (no) & 23.4 \\
\hline Cost-related medication non-adherence status & 13.4 \\
\hline
\end{tabular}

Note: $\mathrm{n}=1,017$ (the observed sample size); \% and mean were corrected by sampling weights.

Lack of help was reported by almost a quarter of participants.

Tables 2 and 3 show the proportion of individuals reporting CRN stratified by covariates previously described as associated with CRN and by social capital measures. Schooling, self-rated health, number of self-reported chronic diseases, private health insurance coverage, and frequency of physician-patient dialogue about health/treatment were all significantly associated with CRN ( $\mathrm{p}<0.05)$. With respect to social capital measures, the perception of attachment to the neighbourhood and perception of help were significantly associated with CRN ( $\mathrm{p}<0.05)$.

Significant results $(\mathrm{p}<0.05)$ of the multivariate analysis of factors associated with CRN are presented in Table 4. Elderly people with a better perception of attachment to the neighbourhood, and those covered by private health insurance had a significant reduction in prevalence of reporting CRN. On the other hand, poor self-rated health, the presence of more chronic diseases, and a lower frequency of physician-patient dialogue about health/treatment were associated with significantly higher prevalence of CRN.

\section{Discussion}

The literature suggests that the relationship between patients' out-of-pocket medication costs and adherence is complex and may be modified by multiple contextual factors. In this population-based study, we found evidence that low levels of social capital appear to be associated with cost-related medication non-adherence. Indeed, among the elderly, a low perception of attachment to the neighbourhood contributes independently to CRN.

Despite the lack of other similar studies to directly compare with these results, we believe similar findings could be expected, since there is solid evidence linking higher stocks of social capital with better health outcomes 16,17,18,19,34.

The mechanism linking social capital and CRN remains to be elucidated, but it is possible that high stocks of social capital can act as a buffer against health inequities, helping people to access services and resources 35 , such as the provision of medicines. In particular, those elderly with a high perception of attachment to their neighbourhood probably have healthier behaviours 36 , such as adherence to medical prescrip- 
Univariate association between sociodemographic characteristics and health conditions with cost-related medication non-adherence. Greater Metropolitan Region of Belo Horizonte, Minas Gerais State, Brazil, 2003.

\begin{tabular}{|c|c|c|c|}
\hline \multirow[t]{2}{*}{ Characteristics } & \multicolumn{2}{|c|}{ Cost-related medication non-adherence } & \multirow[t]{2}{*}{ PR $(95 \% \mathrm{Cl})$} \\
\hline & $\mathbf{n}$ & $\%$ & \\
\hline \multicolumn{4}{|l|}{ Sociodemographic } \\
\hline \multicolumn{4}{|l|}{ Gender } \\
\hline Male & 49 & 11.4 & Reference \\
\hline Female & 101 & 13.8 & $1.15(0.79-1.76)$ \\
\hline \multicolumn{4}{|l|}{ Age (years) } \\
\hline $60-69$ & 88 & 14.2 & Reference \\
\hline $70-79$ & 45 & 10.5 & $0.68(0.46-1.01)$ \\
\hline $80+$ & 17 & 13.9 & $1.03(0.62-1.74)$ \\
\hline \multicolumn{4}{|l|}{ Skin colour } \\
\hline White & 56 & 10.6 & Reference \\
\hline Non-white & 94 & 15.1 & $1.37(0.96-1.95)$ \\
\hline \multicolumn{4}{|l|}{ Schooling (years) } \\
\hline $0-3$ & 78 & 15.2 & Reference \\
\hline $4-7$ & 53 & 14.2 & $0.99(0.68-1.43)$ \\
\hline $8+$ & 19 & 7.2 & $0.43(0.24-0.77)$ \\
\hline \multicolumn{4}{|l|}{ Health conditions } \\
\hline \multicolumn{4}{|l|}{ Self-rated health } \\
\hline Excellent/Good & 26 & 6.1 & Reference \\
\hline Fair & 70 & 13.7 & $2.44(1.42-4.22)$ \\
\hline Poor/Very poor & 54 & 28.2 & $4.69(2.68-8.20)$ \\
\hline \multicolumn{4}{|c|}{ Number of self-reported chronic diseases } \\
\hline None & 8 & 3.8 & Reference \\
\hline 1 & 30 & 8.2 & $2.82(1.12-7.10)$ \\
\hline 2 & 38 & 14.1 & $4.63(1.87-11.45)$ \\
\hline$\geq 3$ & 74 & 21.2 & $7.18(2.99-17.18)$ \\
\hline \multicolumn{4}{|l|}{ Health system } \\
\hline \multicolumn{4}{|c|}{ Private health insurance coverage } \\
\hline No & 109 & 17.1 & Reference \\
\hline Yes & 40 & 8.1 & $0.49(0.33-0.73)$ \\
\hline \multicolumn{4}{|c|}{ Frequency of physician-patient dialogue about health/treatment } \\
\hline Always/Most of the time & 122 & 12.2 & Reference \\
\hline Rarely/Never & 19 & 32.7 & $2.72(1.73-4.27)$ \\
\hline
\end{tabular}

PR ( $95 \% \mathrm{Cl})$ : prevalence ratio ( $95 \%$ confidence interval); $\mathrm{n}$ : the observed sample size; $\%$ : percentages corrected by sampling weights.

tions 37 . Those elderly might directly benefit from the effects of belonging to a community based on common interests and feelings, and cultural or leisurely pursuits, which may all influence the community member's health 36 .

An independent association between CRN and other covariates, like private health insurance coverage, self-rated health status, number of chronic diseases, and frequency of physicianpatient dialogue about health/treatment was described previously ${ }^{31}$. The results of the present study add to those from the earlier study to show that this association persists even after adjustments for social capital covariates.
Although this research provides a more detailed picture of cost-related medication nonadherence as compared to previous studies, some caveats must be considered. First, there is no agreement regarding the definition and exact components of social capital, particularly in the context of public health 15,34. Meanwhile, despite controversies in the literature, we considered a multidimensional approach of social capital, using measures of neighbourhood trust, perception of attachment to the neighbourhood, perception of physical environment, and perception of help that were designed to mirror previous literature on social capital 17,23,24,25,26. Despite considerable 
Univariate association between individual measures of social capital and cost-related medication non-adherence. Greater Metropolitan Region of Belo Horizonte, Minas Gerais State, Brazil, 2003.

\begin{tabular}{|c|c|c|c|}
\hline \multirow[t]{2}{*}{ Individual measures of social capital } & \multicolumn{2}{|c|}{ Cost-related medication non-adherence } & \multirow[t]{2}{*}{ PR $(95 \% \mathrm{Cl})$} \\
\hline & $\mathrm{n}$ & $\%$ & \\
\hline Low & 117 & 13.7 & Reference \\
\hline High & 23 & 12.3 & $0.91(0.59-1.42)$ \\
\hline \multicolumn{4}{|c|}{ Perception of attachment to the neighbourhood } \\
\hline \multicolumn{4}{|l|}{ Perception of physical environment } \\
\hline Low & 66 & 16.3 & Reference \\
\hline High & 74 & 11.8 & $0.72(0.51-1.02)$ \\
\hline \multicolumn{4}{|l|}{ Perception of help } \\
\hline No & 41 & 18.6 & Reference \\
\hline
\end{tabular}

PR (95\% Cl): prevalence ratio (95\% confidence interval); n: observed sample size; \%: percentages corrected by sampling weights.

disagreement as to whether social capital is a group-level or individual phenomenon 14,15,34,38, our study chose an individual-level analytical strategy, and we found an independent contribution to CRN by a social capital element. According to Moore et al. 39 , the communitarian approach assumes that social capital is a property of communities/neighbourhoods. However, living in the same neighbourhood does not enable people to have the same stocks of social capital 40 . In fact, the individual is the repository of societal norms and values, and it is at the individual level that people use personal social networks to strengthen social support, social influence, social engagement, and attachment to access scarce resources 11,41 . We examined people's perceptions of their subjective social context that may provide a crude but adequate substitute for grouplevel observations 42 .

Given the cross-sectional nature of the study, we cannot deduce causal relationships between cost-related medication non-adherence and related factors, but merely describe probable associations. However, one of the current study's strengths is that (to the best of our knowledge) it represents the first effort at examining the association between CRN and social capital.

In conclusion, the main finding of our study - the evidence of effect of social capital on CRN - suggests that future research on CRN should include the social context in order to achieve a more complete understanding of this complex phenomenon. Although the underlying path for this particular association remains elusive and the direction of causality cannot be established firmly with the present design, we believe that health policy could use such information, for instance, to establish initiatives to intensify the involvement between the elderly and their community to assist them in taking their medication as prescribed, despite cost pressures. 


\section{Resumo}

Para investigar a associação entre percepções de capital social e subutilização de medicamentos por motivos financeiros entre idosos, foram analisados dados de 1.134 participantes do Inquérito de Saúde dos Adultos na Região Metropolitana de Belo Horizonte, Minas Gerais, Brasil. A subutilização foi menor para idosos com maior coesão ao bairro de moradia ( $R P=$ 0,68; IC95\%: 0,50-0,94) e com cobertura pela medicina suplementar ( $R P=0,64$; IC95\%: 0,45-0,93). Por outro lado, essa prevalência foi significativamente maior para idosos com pior autopercepção de saúde (razoável, $R P=1,66$; IC95\%: 0,95-2,90; e ruim/muito ruim, $R P=2,62$; IC95\%: 1,46-4,71), com múltiplas condições crônicas (duas, $R P=3,45$; IC95\%: 1,38-8,62; e três ou mais, $R P=4$,42; IC95\%: 1,74-11,25) e para aqueles que raramente ou nunca obtêm do profissional de saúde esclarecimentos sobre sua saúde/tratamento (RP = 1,91; IC95\%: 1,16-3,13). Os resultados apontam para a necessidade de incluir o contexto social em futuras pesquisas sobre o tema.

Adesão à Medicação; Condições Sociais; Farmacoepidemiologia; Idoso

\section{Contributors}

T. C. B. Luz was responsible for the conception, planning, analysis and interpretation of the results of the study and drafting the manuscript. A. I. Loyola Filho contributed with the research project's planning, interpretation of the results and revision of the manuscript content. M. F. Lima-Costa participated in the analysis and interpretation of data, critical revision of the manuscript for important intellectual content and approval of the final version of the paper.

\section{References}

1. Soumerai SB, Pierre-Jacques M, Zhang F, Ross-Degnan D, Adams AS, Gurwitz J, et al. Cost-related medication non-adherence among elderly and disabled Medicare beneficiaries: a national survey 1 year before the Medicare drug benefit. Arch Intern Med 2006; 166:1829-35.

2. Safran DG, Neuman P, Schoen C, Montgomery JE, Li W, Wilson IB, et al. Prescription drug coverage and seniors: how well are states closing the gap? Health Aff (Millwood) 2002; Suppl Web Exclusives:W253-68.

3. Hughes CM. Medication non-adherence in the elderly. How big is the problem? Drugs Aging 2004; 21:793-811.

4. Mojtabai R, Olfson M. Medication costs, adherence, and health outcomes among Medicare beneficiaries. Health Aff (Millwood) 2003; 22:220-9.

5. Tamblyn R, Laprise R, Hanley JA, Abrahamowicz M, Scott S, Mayo N, et al. Adverse events associated with prescription drug cost-sharing among poor and elderly persons. JAMA 2001; 285:421-9.
6. Safran DG, Neuman P, Schoen C, Kitchman MS, Wilson IB, Cooper B, et al. Prescription drug coverage and seniors: findings from a 2003 national survey. Health Aff (Millwood) 2005; Suppl Web Exclusives:W5-152-W5-166.

7. Piette JD, Heisler M, Wagner TH. Cost-related medication underuse among chronically ill adults: the treatments people forgo, how often, and who is at risk. Am J Public Health 2004; 94:1782-7.

8. Piette JD, Heisler M, Horne R, Caleb Alexander G. A conceptually based approach to understanding chronically ill patients' responses to medication cost pressures. Soc Sci Med 2006; 62:846-57.

9. Briesacher BA, Gurwitz JH, Soumerai SB. Patients at-risk for cost-related medication nonadherence: a review of the literature. J Gen Intern Med 2007; 22:864-71.

10. Subramanian SV, Lochner KA, Kawachi I. Neighborhood differences in social capital: a compositional artefact or a contextual construct? Health Place 2003; 9:33-44. 
11. Portes A. Social capital: its origins and applications in modern sociology. Annu Rev Sociol 1998; 24:1-24.

12. Coleman JS. Social capital in the creation of human capital. AJS 1988; 94 Suppl:S95-120.

13. Putnam RD, Leonardi R, Nanetti RY. Making democracy work: civic traditions in modern Italy. Princeton: Princeton University Press; 1993.

14. Szreter S, Woolcock M. Health by association? Social capital, social theory, and the political economy of public health. Int J Epidemiol 2004; 33:650-67.

15. Macinko J, Starfield B. The utility of social capital in research on health determinants. Milbank Q 2001; 79:387-427.

16. Schultz J, O’Brien AM, Tadesse B. Social capital and self-rated health: results from the US 2006 social capital survey of one community. Soc Sci Med 2008; 67:606-17.

17. Baron-Epel O, Weinstein R, Haviv-Mesika A, GartySandalon N, Green MS. Individual-level analysis of social capital and health: a comparison of Arab and Jewish Israelis. Soc Sci Med 2008; 66:900-10.

18. Kawachi I, Kennedy BP, Glass R. Social capital and self-rated health: a contextual analysis. Am J Public Health 1999; 89:1187-93.

19. Nilsson J, Rana AK, Kabir ZN. Social capital and quality of life in old age: results from a cross-sectional study in rural Bangladesh. J Aging Health 2006; 18:419-34.

20. Laporte A, Nauenberg E, Shen L. Aging, social capital, and health care utilization in Canada. Health Econ Policy Law 2008; 3:393-411.

21. Lima-Costa MFF. A saúde dos adultos na Região Metropolitana de Belo Horizonte: um estudo epidemiológico de base populacional. Belo Horizonte: Rona Editora; 2004.

22. Streiner DL, Norman GR. Health measurement scales: a practical guide to their development and use. Oxford: Oxford University Press; 1989.

23. Нyуррӓ MT, Mäki J. Individual-level relationships between social capital and self-rated health in a bilingual community. Prev Med 2001; 32:148-55.

24. Kawachi I, Kennedy BP, Lochner K, Prothrow-Stith D. Social capital, income inequality and mortality. Am J Public Health 1997; 87:1491-8.

25. Araya R, Dunstan F, Playle R, Thomas H, Palmer S, Lewis G. Perceptions of social capital and built environment and mental health. Soc Sci Med 2006; 62:3072-83

26. Pampalon R, Hamel D, De Koninck M, Disant MJ. Perception of place and health: differences between neighbourhoods in the Québec City region. Soc Sci Med 2007; 65:95-111.

27. Wilson IB, Schoen C, Neuman P, Strollo MK, Rogers $\mathrm{WH}$, Chang $\mathrm{H}$, et al. Physician-patient communication about prescription medication nonadherence: a 50-state study of America's seniors. J Gen Intern Med 2007; 22:6-12.
28. Klein D, Turvey C, Wallace R. Elders who delay medication because of cost: health insurance demographic health and financial correlates. Gerontologist 2004; 44:779-87.

29. Taira DA, Iwane KA, Chung RS. Prescription drugs: elderly enrolee reports of financial access receipt of free samples and discussion of generic equivalents related to type of coverage. Am J Manag Care 2003; 9:305-12.

30. Steinman MA, Sands LP, Covinsky KE. Self-restriction of medications due to cost in seniors without prescription coverage. J Gen Intern Med 2001; 16:793-9.

31. Luz TCB, Loyola Filho AI, Lima-Costa MF. Estudo de base populacional da subutilização de medicamentos por motivos financeiros entre idosos na Região Metropolitana de Belo Horizonte, Minas Gerais, Brasil. Cad Saúde Pública 2009; 25:1578-86.

32. Lima-Costa MF, Firmo JOA, Uchôa E. Differences in self-rated health among older adults according to socioeconomic circumstances: the Bambuí Health and Aging Study. Cad Saúde Pública 2005; 21:830-9.

33. Zou G. A modified Poisson regression approach to prospective studies with binary data. Am J Epidemiol 2004; 159:702-6.

34. Kawachi I, Kim D, Coutts A, Subramanian SV. Commentary: reconciling the three accounts of social capital. Int J Epidemiol 2004; 33:682-90.

35. Veenstra G, Luginaah I, Wakefield S, Birch S, Eyles J, Elliott S. Who you know, where you live: social capital, neighbourhood and health. Soc Sci Med 2005; 60:2799-818.

36. Stansfeld SA. Social support and social cohesion. In: Marmot M, Wilkinson RG, editors. Social determinants of health. 2nd Ed. New York: Oxford University Press; 2006. p. 148-71.

37. Berkman LF, Glass T, Brissette I, Seeman TE. From social integration to health: Durkheim in the new millennium. Soc Sci Med 2000; 51:843-57.

38. Poortinga W. Social capital: an individual or collective resource for health? Soc Sci Med 2006; 62: 292-302.

39. Moore S, Haines V, Hawe P, Shiell A. Lost in translation: a genealogy of the "social capital" concept in public health. J Epidemiol Community Health 2008; 60:729-34.

40. Gatrell AC, Popay J, Thomas C. Mapping the determinants of health inequalities in social space: can Bourdieu help us? Health Place 2004; 10:245-57.

41. Veenstra G. Social capital, SES and health: an individual-level analysis. Soc Sci Med 2000; 50:619-29.

42. Lillbacka R. Measuring social capital: assessing construct stability of various operationalizations of social capital in a Finnish sample. Acta Sociol 2006; 49:201-20.

Submitted on $06 /$ Nov/2009

Final version resubmitted on 29/Jun/2010

Approved on 29/Sep/2010 